\title{
Detection of Plasmodium using filter paper and nested PCR for patients with malaria in Sanliurfa, in Turkey
}

Nebiye Yentur Doni ${ }^{1 *}$, Fadile Yildiz Zeyrek ${ }^{2}$ and Adnan Seyrek ${ }^{3}$

\begin{abstract}
Background: The objective of this study to detect Plasmodium and a subspecies of Plasmodium using filter paper in malaria endemic province, Sanliurfa, in Turkey, compare the results of nested PCR (nPCR) with microscopy for the diagnosis of malaria and present the epidemiological data of malaria.

Methods: This study was carried out in malaria-endemic Sanliurfa between 2008 and 2011. Finger prick blood samples, thick and thin Giemsa-stained blood smears, were collected from 153 malaria-suspected farmworkers. The Giemsa-stained blood smears were examined microscopically. The obtained DNA products, extracted from bloodspotted filter papers or from the thick blood smears, were analysed by nPCR to amplify the 185 ssrRNA Plasmodium gene with genus and specific primers. The results of the microscopy were compared to the nPCR results.

Results: Of the specimens, $7.2 \%$ were determined as Plasmodium-positive by microscopy, whereas $9.8 \%$ were determined as Plasmodium-positive by nPCR. Of the positive Plasmodium specimens, $93.33 \%$ were identified as $P$. vivax. Four out of the 15 specimens that were microscopically diagnosed as negative were Plasmodium-positive with nPCR. When compared to the microscopy, the sensitivity, specificity, and positive predictive values of the nPCR were determined as 100, 97.2 and $73.3 \%$, respectively. nPCR was determined to be more sensitive and specific than microscopy.
\end{abstract}

Conclusions: This study revealed that the accurate diagnosis of malaria by nPCR was compulsory in malaria-endemic Sanliurfa and nPCR should be applied routinely in laboratory studies.

Keywords: Dried blood spot testing, Malaria, Microscopy, Nested PCR, Plasmodium vivax, Turkey

\section{Background}

Malaria is the major cause of morbidity and mortality in adults and children worldwide. According to the World Health Organization (WHO), there were an estimated 198 million cases of malaria in 2013, of which approximately $82 \%$ were in the African Region, followed by South-East Asia (12\%), and eastern Mediterranean regions (5\%). About $8 \%$ of the globally estimated cases are due to Plasmodium vivax and this ratio increases to $47 \%$ outside the African continent [1].

Accurate diagnosis is an important tool in the fight against malaria and universal access to a parasitological

\footnotetext{
*Correspondence: n_doni@hotmail.com; n_doni@harran.edu.tr 1 Department of Medical Microbiology, Vocational School of Health Services, Harran University, Ipekyol Avenue No: 1, 63050 Sanliurfa, Turkey Full list of author information is available at the end of the article
}

test is part of the WHO objectives [1]. Microscopy depending on Giemsa-stained blood smears has been considered as the reference gold standard [2-6] for the diagnosis of malaria for more than a century. On the other hand, microscopy techniques fail to detect mixed infections, when one of the Plasmodium species is present at low levels $(<100$ parasites $/ \mathrm{mL})$, or modified by anti-malarial drug treatment $[6,7]$ and it is also a labourintensive procedure and requires well-trained personnel [4]. However, molecular techniques have been capable for the detection and identification of malaria parasites with low and mixed parasitaemia [8]. According to the WHO, PCR was determined as more sensitive and specific than all other techniques. It does, however, require specialized and costly equipment and reagents, as well as laboratory conditions that are often not available in the field $[5,9]$. 
The Southeastern Anatolia Region (GAP) is the most malaria-endemic region, where one of the two largest malaria epidemics of Turkey was occurred in 1994 with 84,345 cases [10]. According to Health Ministry data, it was estimated that $89 \%$ of 36,842 malaria cases were detected in the GAP of Turkey [11].

In the GAP of Turkey, malaria transmission is seasonal, generally occurring between March and October, and shows a marked local distribution [12]. Plasmodium vivax is the only agent of indigenous malaria cases and only imported Plasmodium falciparum cases are seen in Turkey [13-16]. The GAP is one of the relatively less developed regions of the country, comprising nine administrative provinces (Adiyaman, Batman, Diyarbakır, Gaziantep, Kilis, Mardin, Siirt, Sanliurfa, and Sirnak) in the basins of the Euphrates and Tigris, and in Upper Mesopotamia. In this region, improper or excessive use of irrigation channels and deficiency in irrigation water management lead to puddles and standing water near fields. These puddles, standing water, and swamps contribute to the development of parasite larvae and breeding of Anopheles mosquitoes. As reported by the WHO, Anopheles mosquitoes breed in water and each species has its own breeding preference; for example, some prefer shallow collections of fresh water, such as puddles, rice fields, and hoof prints [17]. The GAP has been converted into an appropriate environment including temperature and climate changes for mosquito breeding and the development of parasites. Farm workers living close to puddles, standing water, and swamps have become a risk group for malaria. Many seasonal farmworkers come to Sanliurfa from different parts of Turkey to work in agriculture and many of them move from their home towns to other provinces of Turkey. The seasonal workers raised serious concerns that malaria acquired in Sanliurfa would be disseminated to other regions of Turkey. Sanliurfa is located on the board with Syria where a large influx of displaced persons from neighbouring countries.

These environmental conditions and migration from neighbouring countries result in Sanliurfa being a malaria-endemic province. Generally, the diagnosis of malaria depends on microscopical examination of thick and thin Giemsa-stained blood smears in this study area. There were no data about the diagnosis of malaria using nested PCR (nPCR) in Sanliurfa. This was the first study to compare nPCR and microscopy in Sanliurfa, in Turkey.

In light of these data, the aim of this study was to detect Plasmodium and a subspecies of Plasmodium using filter paper and compare the results of nested PCR (nPCR) with microscopy for accurate malaria diagnosis and present the epidemiological data in Sanliurfa, southeastern Turkey.

\section{Methods}

\section{Study area and population}

This study was conducted between 2008 and 2011 in three towns (Centre of Sanliurfa, Harran, Siverek and Akcakale) of Sanliurfa (latitude: 37.16708, North; longitude: 38.79392, East), where malaria was seen throughout the year with peaks during September to November. Average annual temperature is $19.83{ }^{\circ} \mathrm{C}$ and monthly minimal temperature $-4.3{ }^{\circ} \mathrm{C}$ in January and maximal $44.2{ }^{\circ} \mathrm{C}$ in July. Average annual relative humidity is $45.27 \%$ and rainfall is $518.91 \mathrm{~mm}$ [18].

After explaining the aim of the study, written informed consent was obtained from participants or their parents who work as seasonal farmworkers on agriculture of paddy, cotton, rice fields, etc., or the participants' parents. All of the participants were asked to fill out a standardized questionnaire, which included sociodemographics and living conditions: age, gender, education, the story of malaria of the participant and his/her family in the past, history of travel abroad, presence of a chronic disease, and presence of a sewerage or stream close to their home. The main agent of the indigenous malaria transmission is due to $P$. vivax, and in recent years, foreign originated $P$. falciparum cases were frequently seen in the region [19].

The investigators visited and actively screened Akcakale, Harran, and Siverek (by house-to-house screening) with malaria experts and technicians from the Malaria Eradication Centre of Sanliurfa. In this study, a total of 153 malaria-suspected farmworkers or farmworkers' children with at least a few malaria symptoms, including fever, headache, chills, and vomiting were determined.

\section{Sample collection}

An aliquot of venous blood (100-200 $\mu \mathrm{L})$ was taken by finger prick from 153 malaria-suspected farmworkers or their children, adsorbed onto Whatman ${ }^{\circledR} 31 \mathrm{ETCHR}$ filter paper (Whatman, Piscataway, NJ), air-dried, and stored at room temperature until DNA extraction.

\section{Microscopic determination of the parasite, and counting the parasitemia}

Thin and thick Giemsa-stained blood smears were prepared during the collection of the blood specimens. All of the blood smears were examined by two experienced microscopists (one was an expert from the Sanliurfa National Malaria Eradication Centre and other was a study investigator) blinded to each other's results according to the WHO competency assessment protocol [20]. The blood smears were then independently reexamined by two experienced microscopists. A smear was considered to be negative when no parasites were detected in the total area, where 200 WBCs were observed either by 
experts from the Sanliurfa Malaria Eradication Centre or the study investigators as described previously [21]. Thick blood smears were used to calculate parasitaemia (parasites/microlitre of blood), as described by Zeyrek et al. [22].

\section{DNA extraction from filter paper}

DNA was extracted from filter blots using the QIAmp DNA Blood Mini Kit (Qiagen, Germany) according to the manufacturer's instructions.

\section{DNA extraction from thick blood smears}

Before the extraction of DNA, the slides were cleaned to remove oil residues. Approximately $20 \mu \mathrm{L}$ of Tris-EDTA (TE) buffer was put on the thick blood smear. Whatman filter paper was cut into strips and placed on the slide to absorb the buffer. The filter paper absorbed the blood from the thick blood smear, and was held by sterile forceps and put into a $1.5 \mathrm{~mL}$ centrifuge tube. Next, the DNA from the filter paper was extracted using the QIAmp DNA Blood Mini Kit (Qiagen, Germany) according to the manufacturer's instructions.

\section{DNA amplification by $\mathrm{nPCR}$}

The nPCR amplification strategy was used for genotyping the $18 \mathrm{~S}$ ssrRNA genes of $P$. vivax, $P$. falciparum, Plasmodium ovale, and Plasmodium malariae, in which specific primers were used, as described by Snounou et al. [23]. For the first amplification reaction, $1 \mu \mathrm{L}$ of the template DNA extracted from the blood samples spotted onto filter papers was used (Nested 1), in which the fragment extended by rPLU1 and rPLU5 (Table 1) was amplified. Next, $1 \mu \mathrm{L}$ of the product of the first amplification reaction was used as a template DNA for the secondary amplification reaction (Nested 2), in which the genus-specific (rPLU3-rPLU4) and species-specific
(rVIV1-rVIV2, rFAL1-rFAL2, rMAL1-rMAL2, and rOVA1-rOVA2) primer pairs were used for each of the four separate reactions [23] (Table 1). The PCR assays were performed using a Gene Amp PCR System 97000 (PE applied biosystems).

All of the amplification reactions were carried out in a total volume of $20 \mu \mathrm{L}$ and in the presence of $10 \mathrm{mM}$ Tris$\mathrm{HCl}, \mathrm{pH} 8.3,50 \mathrm{mM} \mathrm{KCl}, 250 \mathrm{nM}$ of each oligonucleotide primers, $125 \mu \mathrm{M}$ of each of the four deoxyribonucleotide triphosphates (dNTPs), $2.5 \mathrm{mM} \mathrm{MgCl} 2$, and 0.4 units of Taq DNA polymerase (Qiagen, Germany).

The cycling parameters for the PCR were as follows: step 1, initial denaturation at $95^{\circ} \mathrm{C}$ for $5 \mathrm{~min}$; step 2, annealing at $\mathrm{X}{ }^{\circ} \mathrm{C}$ for $2 \min \left(\mathrm{X}=58^{\circ} \mathrm{C}\right.$ for Nested 1 , $\mathrm{X}=64{ }^{\circ} \mathrm{C}$ for Nested 2); step 3 , extension at $72{ }^{\circ} \mathrm{C}$ for $2 \mathrm{~min}$; step 4 , denaturation at $94{ }^{\circ} \mathrm{C}$ for $1 \mathrm{~min}$; step 5 , repeat steps 2-4 for a total of 25 cycles (Nested 1) or 30 cycles (Nested 2); step 6, final annealing at $\mathrm{X}{ }^{\circ} \mathrm{C}$ for $2 \mathrm{~min}$ $\left(\mathrm{X}=58{ }^{\circ} \mathrm{C}\right.$ for Nested $1, \mathrm{X}=64{ }^{\circ} \mathrm{C}$ for Nested 2); step 7 , final extension at $72{ }^{\circ} \mathrm{C}$ for $5 \mathrm{~min}$; and step 8 , reducing the temperature to $4{ }^{\circ} \mathrm{C}$. The PCR products were stored at $4{ }^{\circ} \mathrm{C}$ until analysis.

The amplified products were electrophoresed on $2 \%$ agarose gels performed in Tris-borate-EDTA for $P$. vivax, $P$. falciparum, P. malariae, and $P$. ovale, and stained with ethidium bromide for visual detection by ultraviolet transilluminator.

\section{Ethical approval}

All procedures performed in this study involving human participants were in accordance with the ethical standards of the institutional and/or national research committee and with the 1964 Helsinki declaration and its later amendments or comparable ethical standards. This study was approved by the Ethics Committee of the Faculty of Medicine at Firat University (22.09.2011/13/13).

Table 1 Schematic representation of the Plasmodium ssrRNA genes and nPCR protocol [13]

\begin{tabular}{|c|c|c|c|c|}
\hline Species & PCR product & Primer & Sequence & Reaction \\
\hline Plasmodium genus-specific & $235 \mathrm{bp}$ & $\begin{array}{l}\text { rPLU3 } \\
\text { rPLU4 }\end{array}$ & $\begin{array}{l}\text { TTTTTATAAGGATAACTACGGAAAAGCTGT } \\
\text { TACCCGTCATAGCCATGTTAGGCCAATACC }\end{array}$ & Nested 2 \\
\hline Plasmodium genus-specific & $1.6-1.7 \mathrm{~kb}$ & $\begin{array}{l}\text { rPLU1 } \\
\text { rPLU5 }\end{array}$ & $\begin{array}{l}\text { TCAAAGATTAAGCCATGCAAGTGA } \\
\text { CCTGTTGTTGCCTTAAACTTC }\end{array}$ & Nested 1 \\
\hline \multicolumn{5}{|l|}{ Plasmodium species-specific } \\
\hline P. falciparum & $206 \mathrm{bp}$ & $\begin{array}{l}\text { rFAL1 } \\
\text { rFAL2 }\end{array}$ & $\begin{array}{l}\text { TTAAACTGGTTTGGGAAAACCAAATATATT } \\
\text { ACACAATGAACTCAATCATGACTACCCGTC }\end{array}$ & Nested 2 \\
\hline P. malaria & $145 \mathrm{bp}$ & $\begin{array}{l}\text { rMAL1 } \\
\text { rMAL2 }\end{array}$ & $\begin{array}{l}\text { ATAACATAGTTGTACGTTAAGAATAACCGC } \\
\text { AAAATTCCCATGCATAAAAAATTATACAAA }\end{array}$ & Nested 2 \\
\hline P. ovale & 226 bp & $\begin{array}{l}\text { rOVA1 } \\
\text { rOVA2 }\end{array}$ & $\begin{array}{l}\text { ATCTCTTTTGCTATTTTTTAGTATTGGAGA } \\
\text { ATCTAAGAATTTCACCTCTGACATCTG }\end{array}$ & Nested 2 \\
\hline P. vivax & $121 \mathrm{bp}$ & $\begin{array}{l}\text { rVIV1 } \\
\text { rVIV2 }\end{array}$ & $\begin{array}{l}\text { CGCTTCTAGCTTAATCCACATAACTGATAC } \\
\text { ACTTCCAAGCCGAAGCAAAGAAAGTCCTTA }\end{array}$ & Nested 2 \\
\hline
\end{tabular}




\section{Statistical analysis}

Data entry and analyses were performed using Statistical Package for the Social Sciences 11.5. The descriptive data was given as a means with standard deviations, frequency counts, and percentages. Considered the gold standard in the diagnosis of malaria diagnostic methods based on microscopic diagnosis of malaria in the nPCR analysis of validity and reliability of the methodology for the determination of epidemiological research methods were used. nPCR analysis' sensitivity, specificity, reliability, positive predictive value (PPV), negative predictive value (NPV) were analysed.

\section{Results}

\section{Study area and population}

The study sample comprised 153 suspected malaria patients, aged between 1 month and 77 years, from three provinces of Sanliurfa between 2008-2011 (Table 2) [24]. The mean age of the participants was $21.10 \pm 16.10$, of which $50.4 \%$ were female and $49.6 \%$ were male. Of the participants, $61.54 \%$ had headaches, chills, fever, and sweats; $15.39 \%$ had nausea, vomiting, weakness, and tiredness; and $23.07 \%$ had fever and headaches. It was found that $38.2 \%$ of the participants had been treated by chloroquine and primaquine during our survey, but $61.8 \%$ had not used any drugs for malaria.

In the present study, $7.2 \%$ (11) of the specimens were detected as Plasmodium-positive by microscopy. On the other hand, of all the 153 patients, $9.8 \%$ (15) were determined as Plasmodium-positive using nPCR with genus specific primers (Fig. 1). The investigators were in doubt if the results of the nPCR were false-positive or not and the results of microscopical examination were false-negative or not. Two experienced microscopists examined the blood smears of the same patients twice and found that $7.2 \%$ of the blood smears were still Plasmodium-positive and all of them were identified as only $P$. vivax by microscopic examination. According to the thin blood smears, the mean parasitaemia density was estimated as $4678.18 \pm 3497.06$ parasites $/ \mu \mathrm{L}$ (range $=640-9760$ parasites $/ \mu \mathrm{L})($ Table 2$)$. After twice repeating the nPCR, 15 patients were still Plasmodium-positive with $\mathrm{nPCR}$. The investigators confirmed that all four specimens that were microscopically diagnosed as negative were determined as positive by nPCR. According to the results of the nPCR for malaria, these four patients were treated with chloroquine. After treatment with chloroquine, the symptoms of malaria in these suspected patients disappeared. Treatment and elimination of the malaria symptoms confirmed the accuracy of the nPCR that we found superior to microscopy. The WHO recommends that malaria should be confirmed by parasite-based diagnosis before giving treatment [25].

A total of 15 samples were diagnosed as Plasmodium and $93.33 \%$ of them were $P$. vivax by nested PCR; three samples from Siverek, eight from Harran in 2008, three from Harran in 2009 and one from Akcakale in 2011. Although these samples were limited in small number size $(n=15)$, they were included in $26.8 \%$ of total samples $(n=56)$ in study provinces: 43 in 2008, eight in 2009, four in 2010, one in 2011 (Table 2, number of malaria cases in study provinces). The patient diagnosed as $P$. vivax in Akcakale was the only case in 2011. The patient lived in a village which was located on the border with Syria. The patient's house and Syrian houses were located face to face.

Table 2 The distribution of the malaria cases were according to the provinces of Sanliurfa [24]

\begin{tabular}{|c|c|c|c|c|c|c|c|c|c|c|c|c|}
\hline \multirow[t]{2}{*}{ Provinces } & \multicolumn{11}{|l|}{ Years } & \multirow[t]{2}{*}{ Total } \\
\hline & 2001 & 2002 & 2003 & 2004 & 2005 & 2006 & 2007 & 2008 & 2009 & 2010 & 2011 & \\
\hline Centre & 41 & 44 & 36 & 23 & 5 & 2 & 1 & 18 & 1 & 0 & 0 & 173 \\
\hline Akcakale $^{a}$ & 0 & 0 & 3 & 0 & 0 & 0 & 0 & $0^{b}$ & $0^{b}$ & $0^{b}$ & $1^{\mathrm{b}}$ & 4 \\
\hline Birecik & 30 & 43 & 21 & 19 & 0 & 0 & 3 & 0 & 0 & 0 & 0 & 116 \\
\hline Bozova & 0 & 0 & 0 & 0 & 0 & 0 & 0 & 0 & 0 & 0 & 0 & 0 \\
\hline Ceylanpinar & 346 & 176 & 50 & 17 & 0 & 1 & 1 & 0 & 0 & 0 & 0 & 591 \\
\hline Halfeti & 0 & 0 & 0 & 0 & 0 & 0 & 0 & 0 & 0 & 0 & 0 & 0 \\
\hline Hilvan & 7 & 4 & 4 & 2 & 2 & 5 & 0 & 0 & 0 & 0 & 0 & 24 \\
\hline Siverek $^{a}$ & 529 & 902 & 634 & 397 & 375 & 234 & 49 & $9^{b}$ & $3^{b}$ & $4^{b}$ & $0^{b}$ & 3136 \\
\hline Suruç & 4 & 5 & 6 & 4 & 0 & 2 & 0 & 0 & 0 & 0 & 0 & 21 \\
\hline Viransehir & 159 & 70 & 29 & 18 & 8 & 1 & 5 & 0 & 0 & 0 & 0 & 290 \\
\hline Harran $^{a}$ & 1 & 0 & 0 & 0 & 0 & 0 & 1 & $34^{b}$ & $5^{b}$ & $0^{b}$ & $0^{\mathrm{b}}$ & 40 \\
\hline Toplam & 1117 & 1244 & 783 & 480 & 390 & 245 & 60 & 61 & 9 & 4 & 1 & 4394 \\
\hline
\end{tabular}

a Study provinces of this study

b Number of malaria cases in study provinces 


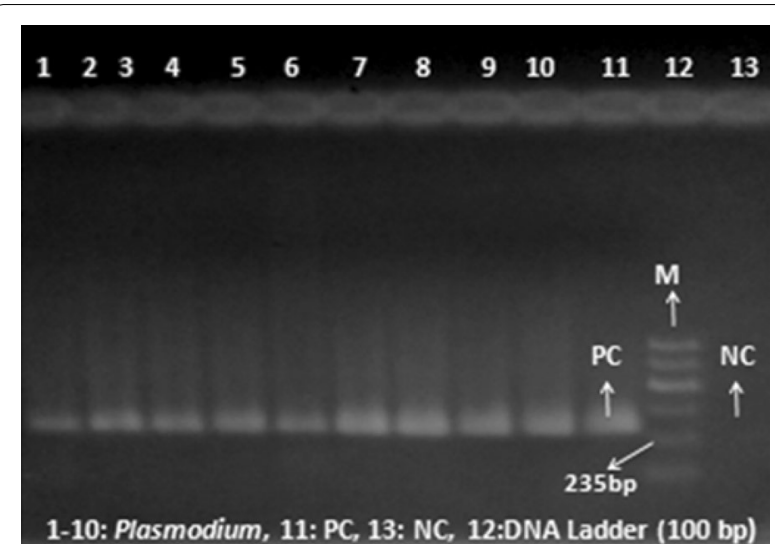

Fig. 1 Agarose gel electrophoresis showing PCR products obtained using genus-specific primers; Lanes 1-10 Plasmodium, Lane 11 positive control, Lane 12 DNA marker, and Lane 13 negative control

The mean age of the patients infected with $P$. vivax was $25.92 \pm 15.46$ (range $=9-60$ years), and $53.3 \%$ were male.

Of the Plasmodium specimens, 14 of 15 (93.33\%) were identified as $P$. vivax (Fig. 2) using species-specific primers (Table 1 ) for the identification of $P$. vivax, $P$. falciparum, $P$. malaria, $P$. ovale, respectively. One of the 15 Plasmodiumpositive samples (Table 3, patient 3) was not identified with the species-specific primers used in this study.

Four out of the 15 specimens that were microscopically diagnosed as negative were positive for Plasmodium with nested-PCR (Table 4).

\section{Statistical analysis}

When compared to the microscopy, the sensitivity, specificity, and positive predictive values of the nPCR were found as 100, 97.2 and $73.3 \%$, respectively.

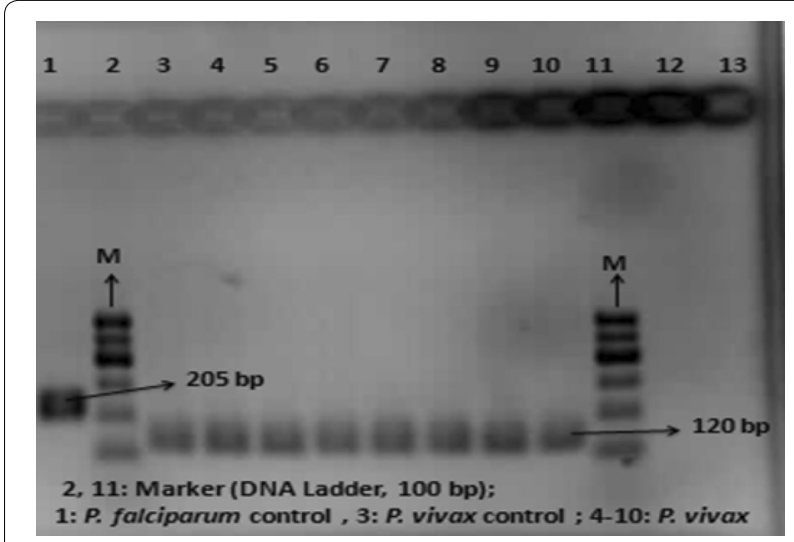

Fig. 2 Agarose gel electrophoresis showing PCR products obtained using species-specific primers; Lane 1 Plasmodium falciparum-positive control, Lane 10 Plasmodium vivax-positive control, Lanes 2 and 11 Marker (DNA Ladder, 100 bp), Lane 12 negative control, Lanes 3-9 Plasmodium vivax

\section{Discussion}

The results of this study indicated that the examination of thick and thin blood smears by microscopy were insufficient for the diagnosis of malaria in this region. This study supported the idea that sensitivity decreases with microscopical tests as parasitaemia falls below 100 parasites/mL and false negatives are observed [2-6, 9, 26, 27]. When microscopy was used as the reference standard, it was found that the sensitivity, specificity, and positive predictive values of the nPCR as 100, 97.2, and $73.3 \%$, respectively. This study emphasized that $\mathrm{nPCR}$ was more sensitive and specific than microscopy, as it has been reported elsewhere [2, 6, 8, 26, 28-32].

Of the detected Plasmodium-positive samples, $93.33 \%$ were detected as P. vivax and $6.77 \%$ was not identified by targeting the $18 \mathrm{~S}$ rRNA gene with the species-specific primers in the present study. According to the microscopical examination of the thick blood smear, it was identified as $P$. vivax. This result might be explained mostly in three ways: first, this patient was diagnosed by the technicians of the Sanliurfa National Malaria Eradication Centre, who only prepare thick and thin Giemsa-stained blood smears. They did not allow the adsorption of the patient's blood onto the filter paper. They only sent the thick and thin blood smears to us for confirmation of the diagnosis of malaria. Hence, the investigators were obliged to extract DNA from the thick blood smears. This might be as a result of using DNA extraction from the thick blood smear. Because, most recently, Scopel et al. reported that the use of DNA extracted from thick blood smears resulted in poor detection of malaria parasites, particularly with parasite densities of less than $20 / \mu \mathrm{L}$ [33]. So, the most probable reason for amplification failure might be that the DNA became degraded or was of poor quality as it was obtained from a stained thick smear. Second, this might be due to their belonging to the newly determined fifth species of Plasmodium. When the patient was asked whether he had travelled to southeast Asia or not, it was seen that the patient had never travelled. So the idea of fifth species of Plasmodium is highly remote moreover the morphology of this parasite is quite distinct from that of $P$. vivax, which was confirmed microscopic diagnosis. Third, it might have been a case of the variant $P$. ovale as the oligonucleotide primer pairs used did not include those that can amplify this variant (Fig. 2).

\section{Conclusions}

This study emphasized that nPCR is an excellent method for obtaining accurate epidemiological data in malaria endemic Sanliurfa (Fig. 3). The diagnosis of Plasmodium by $\mathrm{nPCR}$ might prevent misdiagnosis, incorrect treatment, 
Table 3 Results of the microscopic examination of Plasmodium and nPCR of Plasmodium and subspecies of Plasmodium

\begin{tabular}{lllll}
\hline $\begin{array}{l}\text { Number } \\
\text { of cases }\end{array}$ & $\begin{array}{l}\text { Microscopic } \\
\text { examination }\end{array}$ & $\begin{array}{l}\text { Number of } \\
\text { parasitemia/ } \boldsymbol{\mu L}\end{array}$ & $\begin{array}{l}\text { Diagnosis of } \\
\text { Plasmodium by } \mathbf{n P C R}\end{array}$ & $\begin{array}{l}\text { Diagnosis of subspecies } \\
\text { of } \text { Plasmodium } \text { by } \mathbf{n P C R}\end{array}$ \\
\hline 1 & Positive & 640.00 & Plasmodium & Plasmodium vivax \\
2 & Positive & 960.00 & Plasmodium & Plasmodium vivax \\
3 & Positive & 1200.00 & Plasmodium & - \\
4 & Positive & 1280.00 & Plasmodium & Plasmodium vivax \\
5 & Positive & 1760.00 & Plasmodium & Plasmodium vivax \\
6 & Positive & 5920.00 & Plasmodium & Plasmodium vivax \\
7 & Positive & 6720.00 & Plasmodium & Plasmodium vivax \\
8 & Positive & 7360.00 & Plasmodium & Plasmodium vivax \\
9 & Positive & 7680.00 & Plasmodium & Plasmodium vivax \\
10 & Positive & 8180.00 & Plasmodium & Plasmodium vivax \\
11 & Positive & 9760.00 & Plasmodium & Plasmodium vivax \\
12 & Negative & - & Plasmodium & Plasmodium vivax \\
13 & Negative & - & Plasmodium & Plasmodium vivax \\
14 & Negative & - & Plasmodium & Plasmodium vivax \\
15 & Negative & - & Plasmodium & Plasmodium vivax
\end{tabular}

Table 4 Comparison of the microscopy and nPCR

\begin{tabular}{|c|c|c|c|c|c|c|}
\hline & \multicolumn{6}{|c|}{ Microscopy } \\
\hline & \multicolumn{2}{|c|}{ Positive } & \multicolumn{2}{|c|}{ Negative } & \multicolumn{2}{|c|}{ Total } \\
\hline & $\mathbf{n}$ & $\%$ & $n$ & $\%$ & $\mathrm{n}$ & $\%$ \\
\hline \multicolumn{7}{|l|}{$\mathrm{nPCR}$} \\
\hline Positive & 11 & 73.3 & 4 & 26.7 & 15 & 9.8 \\
\hline Negative & 0 & 0.0 & 138 & 100.0 & 138 & 90.2 \\
\hline Total & 11 & 7.2 & 142 & 92.8 & 153 & 100.00 \\
\hline
\end{tabular}

false positives, false negatives, the emergence and spread of drug resistance, and the transmission of Plasmodium parasites from a malaria-endemic region to other provinces of Turkey. The nPCR was not affected by the subjectivity of the observers. In light of these data, nPCR might be a good and useful complement for clinically suspected but microscopically-negative malaria cases and epidemiological studies of $P$. vivax infections. nPCR might be a huge chance for the detection of low density of malaria parasites, mixed infections and identification asymptomatic carriers and reservoirs of parasites. nPCR in malaria suspected people might be a promising alternative to thick smear for screening for malaria in endemic region. Since, asymptomatic malaria carriers might be the parasite reservoir and responsible for the transmission of malaria in endemic region as it had previously been reported [34, 35]. The accurate diagnosis of Plasmodium and Plasmodium species, detection of Plasmodium DNA by nPCR from filter paper is easy to use and slightly invasive complement in malaria endemic region. As a result of the findings, nPCR is compulsory in Sanliurfa and it should be applied routinely in laboratory studies.

The results of the survey presented indicate that some cases of malaria might be missed by conventional microscopy and warrant the use of sensitive molecular techniques for surveillance; this should be placed in the current context where a large influx of displaced persons from neighbouring countries and some malaria-endemic countries are located in the GAP region. This raises a major concern that a potential re-introduction of malaria might occur in areas where it can rapidly disseminate into the local population. For instance, in the 2012 outbreak registered in the province of Mardin, a single index case of imported malaria with 218 autochthonous cases due to the passing of international truck drivers through intensive control and surveillance studies [36]. 

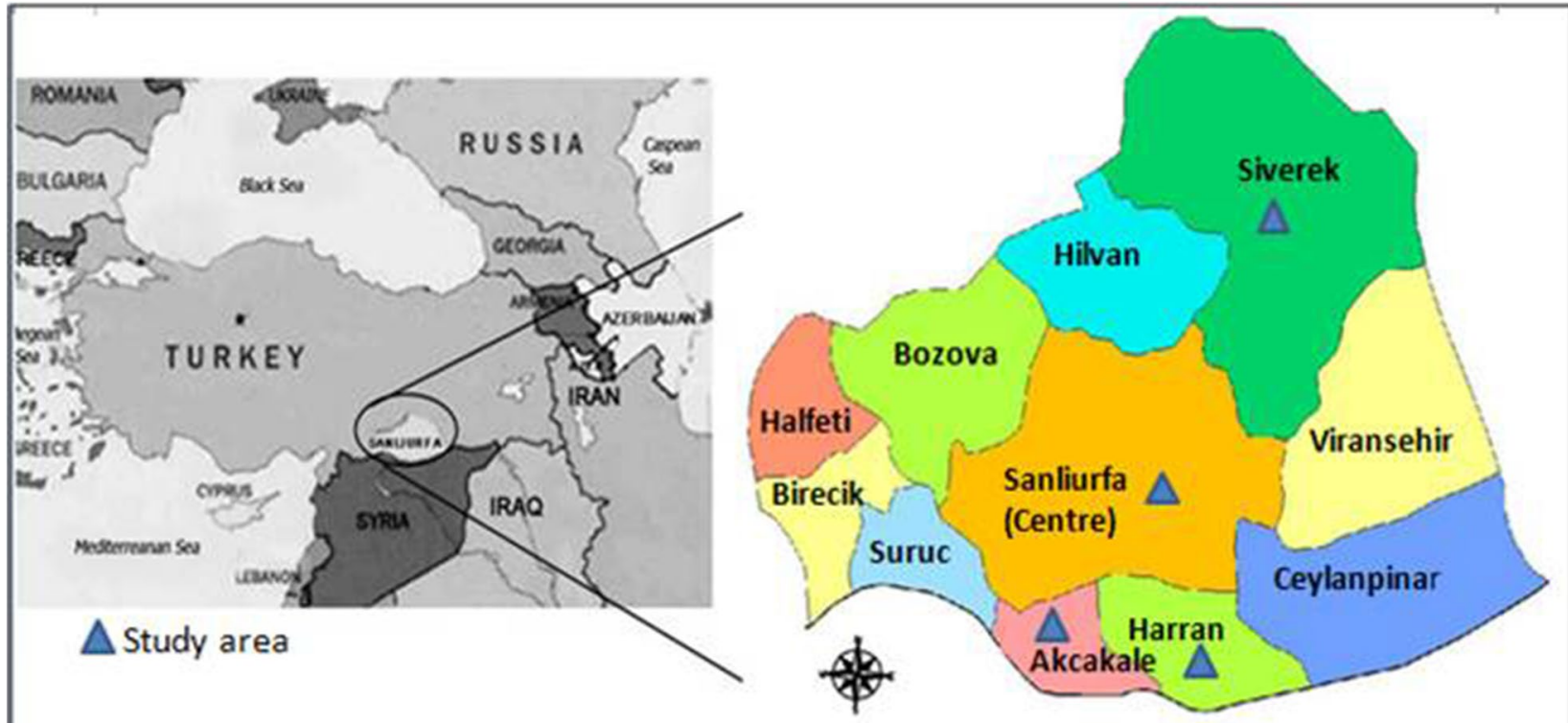

Fig. 3 Study sites. Map of Sanliurfa showing the location of the study regions [22]

\section{Authors' contributions}

AS, NYD, FYZ conceived and designed the study. NYD collected samples from participants. NYD performed microscopic examination. NYD extracted DNA from blood spotted filter papers. NYD carried out all molecular methods, nested PCR, amplified DNA by nested PCR. NYD electrophoresed, stained gels with ethidium bromide for visual detection by ultraviolet transilluminator. NYD performed the statistical analysis. AS, NYD, FYZ participated in its coordination and helped to draft the manuscript. All authors read and approved the final manuscript.

\section{Author details}

1 Department of Medical Microbiology, Vocational School of Health Services, Harran University, Ipekyol Avenue No: 1, 63050 Sanliurfa, Turkey. ${ }^{2}$ Department of Medical Microbiology, Faculty of Medicine, Harran University, Sanliurfa, Turkey. ${ }^{3}$ Department of Medical Microbiology, Faculty of Medicine, Firat University, Elazig, Turkey.

\section{Acknowledgements}

The authors are thankful to the Firat University Scientific Council for supporting this study. The authors also thank all the technicians and experts of the Sanliurfa National Malaria Eradication Centre in the epidemiological studies for their kind cooperation and the volunteer participants/children enrolled to this study. This study (The Project number:TF.11.76) was financially funded by Firat University Scientific Council.

\section{Competing interests}

The authors declare that they have no competing interests.

Received: 8 February 2016 Accepted: 10 May 2016

Published online: 28 May 2016

\section{References}

1. WHO. World malaria report 2014. Trends in infections, cases and deaths. Section 8. Geneva: World Health Organization; 2014. http://www.who.int/ malaria/publications/world_malaria_report_2014/en/.

2. Fuehrer HP, Fally MA, Habler VE, Starzengruber P, Swoboda P, Noed $H$. Novel nested direct PCR technique for malaria diagnosis using filter paper samples. J Clin Microbiol. 2011;49:1628-30. doi:10.1128/ JCM.01792-10

3. Joanny F, Lohr SJ, Engleitner T, Lell B, Mordmuller B. Limit of blank and limit of detection of Plasmodium falciparum thick blood smear microscopy in a routine setting in Central Africa. Malar J. 2014;13:234. doi:10.1186/1475-2875-13-234.

4. Kain KC, Brown AE, Mirabelli L, Webster HK. Detection of Plasmodium vivax by polymerase chain reaction in a field study. J Infect Dis. 1993:168:1323-6.

5. Payne D. Use and limitation of light microscopy for diagnosing malaria at the primary health care level. Bull World Health Organ. 1988;66:621-6.

6. Snounou G, Viriyakosol S, Jarra W, Thaithong S, Brown KN. Identification of the four human malaria parasite species in field samples by the polymerase chain reaction and detection of a high prevalence of mixed infections. Mol Biochem Parasitol. 1993;58:283-92.

7. Scopel KK, Fontes CJ, Nunes AC, Horta MF, Braga EM. High prevalence of Plasmodium malaria infections in a Brazilian Amazon endemic area (Apiacás-Mato Grosso State) as detected by polymerase chain reaction. Acta Trop. 2004;90:61-4

8. Hawkes M, Kain KC. Advances in malaria diagnosis. Expert Rev Anti Infect Ther. 2007;5:485-95. doi:10.1586/14787210.5.3.485

9. New perspectives malaria diagnosis. Report of a joint WHO/USAID consultation. http://www.wpro.who.int/malaria/internet/resources.ashx/RDT/ docs/pdf version/NewPersectivesMalariaDiagnosis.pdf. Accessed 25-27 October 1999.

10. Ozbilgina A, Topluoglu S, Es S, Islek E, Mollahaliloglu S, Erkoc Y. Malaria in Turkey: successful control and strategies for achieving elimination. Acta Trop. 2011;120:15-23. doi:10.1016/j.actatropica.2011.06.011.

11. $\mathrm{MOH}$. Related statistics data of malaria of the presidency of malaria war. Republic of Turkey, Ministry of Health Publication 2003. http://www saglik.gov.tr/TR/belge/1-3416/sitma-savas-daire-baskanliginin-sitma-ileilgili-istati-html.

12. WHO. Guidelines for the treatment of malaria, vol. 2. Geneva: World Health Organization; 2009. p. 13-56.

13. Arslan F, Mert A, Batirel A, Inan A, Balkan II, Nazlican O, et al. Imported Plasmodium falciparum malaria in Istanbul, Turkey: risk factors for severe course and mortality. Trop Doct. 2013;43:129-33. doi:10.1177/0049475513499560

14. Ozsoy MF, Oncul O, Pekkafali Z, Pahsa A, Yenen OS. Splenic complications in malaria: report of two cases from Turkey. J Med Microbiol. 2004;53:1255-8. doi:10.1099/jmm.0.05428-0. 
15. Araz E, Tanyuksel M, Ardic N, Tabuk C. Performance of a commercial immunochromatographic test for the diagnosis of vivax malaria in Turkey. Trans R Soc Trop Med Hyg. 2000;94:55-6.

16. Ardic N, Tanyuksel M, Ozyurt M, Araz E. Is the incidence of malaria decreasing in endemic area of Turkey? New Microbiol. 2005;28:277-80.

17. WHO. Malaria. Key facts. Fact sheet N94 World Health Organization; 2014 [updated March 2014]. http://www.who.int/mediacentre/factsheets/ fs094/en/.

18. TUIK. Turkey's statistical yearbook. Land and climate. Ankara Turkey: Turkish statistical institute; 2012. p. 1-18. http://www.turkstat.gov.tr.

19. WHO. World malaria report 2013 Geneva: World Health Organization; 2013. http://www.who.int/malaria/publications/world_malaria_ report_2013_en/index.html/.

20. WHO. Technical consultation to update the WHO Malaria microscopy quality assurance manual. 26-28 March 2014, Geneva, Switzerland. http://www.who.int/malaria/publications/atoz/mmicroscopy_qam/en/ and http://www.who.int/malaria/publications/malaria_microscopyqa_ report-sep2014-presentations-21to29.pdf.

21. Beadle C, Long GW, Weiss WR, McElroy PD, Maret SM, Oloo AJ, et al. Diagnosis of malaria by detection of Plasmodium falciparum HRP-2 antigen with a rapid dipstick antigen-capture assay. Lancet. 1994;343:564-8.

22. Zeyrek FY, Tachibana S, Yuksel F, Doni N, Palacpac N, Arisue N, et al. Limited polymorphism of the Plasmodium vivax merozoite surface protein 1 gene in isolates from Turkey. Am J Trop Med Hyg. 2010;83:1230-7. doi:10.4269/ajtmh.2010.10-0353.

23. Snounou G, Viriyakosol S, Zhu XP, Jarra W, Pinheiro L, do Rosario VE, et al. High sensitivity of detection of human malaria parasites by the use of nested polymerase chain reaction. Mol Biochem Parasitol. 1993:61:315-20.

24. Yentur Doni N, Yildiz Zeyrek F, Seyrek A, Simsek Z, Gurses G, Topluoglu S. Evaluation of epidemiological data of malaria between 2001-2011 in Sanliurfa, Turkey (Şanlıurfa'da 2001-2011 Yıllarına Ait Sıtma Epidemiyolojik Verilerinin Değerlendirilmesi). Mikrobiyol Bul. 2016;50:307-14. doi: $10.5578 / \mathrm{mb} .21055$.

25. WHO. World malaria report. Geneva: World Health Organization; 2005.

26. Li P, Zhao Z, Wang Y, Xing H, Parker DM, Yang Z, et al. Nested PCR detection of malaria directly using blood filter paper samples from epidemiological surveys. Malar J. 2014;13:175. doi:10.1186/1475-2875-13-175.
27. Safeukui I, Millet P, Boucher S, Melinard L, Fregeville F, Receveur MC, et al. Evaluation of FRET real-time PCR assay for rapid detection and differentiation of Plasmodium species in returning travellers and migrants. Malar J. 2008;7:70. doi:10.1186/1475-2875-7-70.

28. Imwong M, Pukrittayakamee S, Gruner AC, Renia L, Letourneur F, Looareesuwan $S$, et al. Practical PCR genotyping protocols for Plasmodium vivax using Pvcs and Pvmsp1. Malar J. 2005;4:20. doi:10.1186/1475-2875-4-20.

29. Khoo A, Furuta T, Abdullah NR, Bah NA, Kojima S, Wah MJ. Nested polymerase chain reaction for detection of Plasmodium falciparum infection in Malaysia. Trans R Soc Trop Med Hyg. 1996;90:40-1.

30. Roper C, Elhassan IM, Hviid L, Giha H, Richardson W, Babiker H, et al. Detection of very low level Plasmodium falciparum infections using the nested polymerase chain reaction and a reassessment of the epidemiology of unstable malaria in Sudan. Am J Trop Med Hyg. 1996;54:325-31.

31. Singh B, Cox-Singh J, Miller AO, Abdullah MS, Snounou G, Rahman HA. Detection of malaria in Malaysia by nested polymerase chain reaction amplification of dried blood spots on filter papers. Trans R Soc Trop Med Hyg. 1996:90:519-21.

32. Zakeri S, Kakar Q, Ghasemi F, Raeisi A, Butt W, Safi N, et al. Detection of mixed Plasmodium falciparum and $P$. vivax infections by nested-PCR in Pakistan, Iran and Afghanistan. Indian J Med Res. 2010;132:31-5.

33. Scopel KK, Fontes CJ, Nunes AC, Horta MF, Braga EM. Low sensitivity of nested PCR using Plasmodium DNA extracted from stained thick blood smears: an epidemiological retrospective study among subjects with low parasitaemia in an endemic area of the Brazilian Amazon region. Malar J. 2004;3:8. doi:10.1186/1475-2875-3-8.

34. Shahbazi A, Farhadi P, Yerian M, Bazmani A, Nakhjiri SK, Rasouli A, et al. Detection of asymptomatic carriers of Plasmodium vivax among treated patients by nested PCR method in Minab, Rudan and Bashagard, Iran. Iran J Parasitol. 2013:8:586-92.

35. Zakeri S, Najafabadi ST, Zare A, Djadid ND. Detection of malaria parasites by nested PCR in south-eastern, Iran: evidence of highly mixed infections in Chahbahar district. Malar J. 2002;1:2.

36. Topluoglu S, Aydin E, Taylan Ozkan A, Kapcak S, editors. Plasmodium vivax malaria cases in Mardin province in 2012-2014 in Turkey. 25th European congress of clinical microbiology and infectious diseases 2015. Copenhagen.

\section{Submit your next manuscript to BioMed Central and we will help you at every step:}

- We accept pre-submission inquiries

- Our selector tool helps you to find the most relevant journal

- We provide round the clock customer support

- Convenient online submission

- Thorough peer review

- Inclusion in PubMed and all major indexing services

- Maximum visibility for your research

Submit your manuscript at www.biomedcentral.com/submit
BioMed Central 